\title{
Y-pattern Frequency on Lower Molar of Javanese Deutromalayid
}

\author{
Aprian A. Prastya ${ }^{1}$ \\ Department of Anthropology, Universitas Airlangga, \\ Surabaya, Indonesia
}

\author{
Myrtati D. Artaria ${ }^{2}$ \\ (Corresponding Author) at Department of Anthropology, \\ Universitas Airlangga, Jl. Airlangga 4-6, Surabaya 60286, \\ East Java, Indonesia \\ E-mail: myrtati.artaria@ fisip.unair.ac.id
}

\begin{abstract}
In the study of dental anthropology, human dentition varies according to dental traits. There are characteristic dental traits in each population that are useful for knowing the possibility of origin. Geographically, the Sunda-Pacific region is occupied by populations characterising Sundadont's dental traits, which are part Mongoloid, and the Sahul-Pacific is populated by Austromelanesid populations. The island of Java has a majority population of Javanese, which in terms of physical characteristics - skin colour, hair type and colour, epicantus, etc. - are included in the Deutromalayid group, which is also part of the Mongoloid group. This research has studied the frequency of the $\mathrm{Y}$ pattern or Dryopithecus pattern occurrence in the lower molars of the Javanese. The study was conducted by observing 76 individuals, consisting of $\mathbf{7 1}$ dental impressions collected by the second researcher, and 5 skulls belonging to the Laboratory of Anatomy and Histology of Medical School, of Universitas Airlangga. The researchers chose a sample of which the occlusal surface could be observed to see the $Y$ pattern on the crown surface of the tooth. The result of this study indicates that the Y-pattern is frequently found on the first molars. We compared the lower second molar to the frequencies of other populations studied by Scott \& Turner, and we have concluded that Javanese Deuteromalayid has a frequency that is similar to Taiwan Aborigenese and SouthAmerican Indian.
\end{abstract}

Keywords- Dental traits; Javanese; Deutromalayid; Ypattern molar; Dryopithecus pattern

\section{INTRODUCTION}

Each individual has different unique characteristics. The diversity of such characteristics in teeth is influenced by evolution as the source of the variations. Evolution occurs through the process of transformation and genetic change, as a result of the synergistic relationship between genetic factors and environmental factors over a very long time [1]. In the process of evolution, culture also serves as a driving factor for evolution [2]. Culture as a natural selection strategy indirectly affects evolution in terms of changes in the gene frequencies in the population [3]. Thus, human evolution is influenced by genetic and cultural changes in populations that last for a long time to create the diversity of human characteristics that exists now.
Human dentition varies between populations, and is strongly genetically influenced. Dental anthropology focuses on the variety of characteristics found in human teeth [4], [5]. One example of dentition variation found in teeth is non-metrical dental traits

The characteristics of teeth based on the genetic factors affecting dental morphology is useful for determining origin, heredity and parentage in the population.

Some previous observations have indicated that the Javanese living in Surabaya differed from the Arabs living in Surabaya, in the expression of anterior fovea [6]. Comparing the shovel shape of the Javanese to the Manggarai of Flores has revealed a significantly different degree of expression [7].

There are various ethnic groups and cultures that inhabit Indonesia, one of which is the Javanese tribe. The Javanese is the largest ethnic group in Indonesia, approximately 64\% of the total population of Indonesia [8]. The Javanese inhabit most of the area on the island of Java, especially east Java and central Java. The Javanese are also widely dispersed in other areas of Indonesia and the world, but the greatest concentration is on the island of Java. The Javanese belong to the Deutromalayids, which is a part of the Mongoloid group [9].

Dahlberg [10] mentions that the American Indian population has the dental characteristics of large tooth size, shovel-shape, 5-cusped Y-pattern in lower molar one, 5cusped + pattern in the lower molars, and a low frequency of carabelli cusp occurrence [11].

The Y-pattern on the lower molars has been found in Dryopithecus that lived long ago [12]. It is believed to have been seen in the lower molars of modern human until recently [13]. Sub-Saharan African tribes have been identified through dental traits with a high-frequency occurrence of Y-patterns on LM2. Meanwhile, the American Sino population has a low frequency of the occurrence of Y LM2 patterns, and the Sahul-Pacific population has a moderate frequency pattern of Y LM2 [4]. It is interesting to know the percentage of Y-pattern in the Javanese population. How often is it found in the Javanese? 
Would it be closer to the frequency of Sino-Americans, or closer to the Sahul-Pacific population?

\section{MATERIALS AND METHODS}

The sample of this research was from 71 dental impressions of the modern population of Javanese in Surabaya, and from 5 skulls that had their teeth intact. The Y-shaped pattern was observed and scored as presence or absent, based on the pattern shaped by cusp 1 to cusp 4 of the lower molar. The number of cusps is as shown in Figure 1. The Y-pattern or Dryopithecus pattern is a pattern on the lower molar, when the five main cusps have a groove pattern on the occlusal surface revealing a $\mathrm{Y}$ shape. In this pattern, the second and third cusps were in contact (Figure 2).

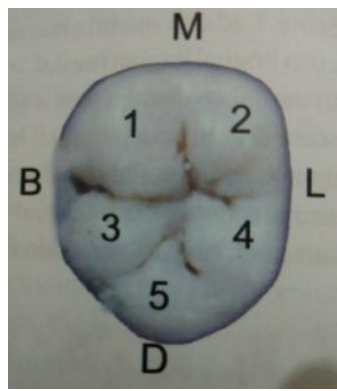

Fig. 1. Position and number of cusp on the lower molar (modified from Fig. 5-13 [4]). B=buccal, L=lingual, $M=$ mesial, $D=$ distal

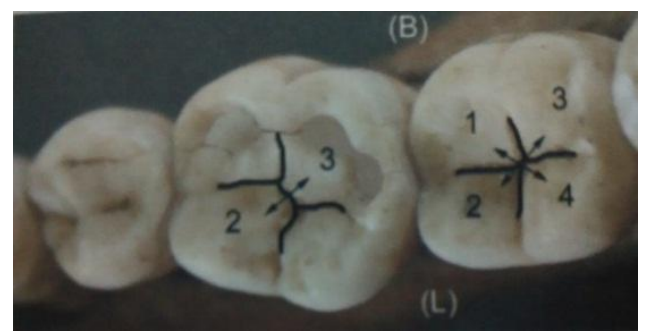

Fig. 2. Y-Pattern in first molar, where second and third cusps were in contact (modified from Fig. 5-14) [4].

\section{RESULTS AND DISCUSSION}

The Occlusal Groove pattern is divided into three types: the Y-pattern, the + pattern, and X-pattern [14]. The three patterns are classified by the form of the grooves shaped by the cusps, and the contacts between each cusp. Standardisation patterns $\mathrm{X}, \mathrm{Y}$, and + were created by Jorgensen [12]. Pattern $Y$ has been found since 25 million years ago in the fossil teeth of Dryopithecus. The Y-pattern or Dryopitecus occlusal groove pattern was first introduced by Gregory in 1916 as a pattern found in LM2 [15].

The discovery of the similarity of Y-patterns in humans and big apes implies a genetic relationship. This pattern has been found in the human population with a variation of frequencies. According to Scott and Turner, Sub-Saharan African tribes have a high-frequency occurrence of Ypatterns on the LM2. Meanwhile, the American Sino population has a low frequency of occurrence of the Y LM2 pattern. The Sahul-Pacific population has a moderate frequency pattern of Y LM2 [4].
TABLE I. FREQUENCY OF Y-PATTERN IN JAVANESE LOWER MOLARS

\begin{tabular}{|c|c|c|}
\hline $\begin{array}{c}\text { Tooth } \\
\text { position }\end{array}$ & frequency & \% \\
\hline LM1 & 27 & 35,5 \\
\hline LM2 & 6 & 7,9 \\
\hline LM3 & 0 & 0.0 \\
\hline
\end{tabular}

Furthermore, based on their observations, Scott and Turner [4] concluded that the frequency of the Y-pattern in Sub-Sahara Africa is 70 percent, and the North Asian, East Asian, America, Pacific and Australian Sudanese groups showed lower frequencies, from 10 to 20 percent. Western Eurasia, Japan, and Melanesia showed a frequency of 20 to 30 percent.

This study found that the Y-pattern frequency on LLM1 is $35.5 \%, 7.9 \%$ in LLM2, and $0.0 \%$ in LLM3. When we compared the results with those of Scott and Turner, this frequency is close to Taiwan's Aboriginal population $(8.7 \%)$, and South-American Indians (7.6\%). Compared to the study by Matsuda [16], the frequency of this study is higher. According to Matsuda, the Y-pattern on the second molars is as low as 4.3 percent in Hokuriku.

TABLE II. FREQUENCIES OF Y-PATTERN IN LM2 AMONG GEOGRAPHIC AND LINGUISTIC GROUPS4 (TABLE 5.4, P.213)

\begin{tabular}{|c|c|c|c|c|}
\hline \multirow[b]{2}{*}{ Major region } & \multirow[b]{2}{*}{ Group } & \multicolumn{3}{|c|}{ LM2 } \\
\hline & & $n$ & Mean \% & $S D$ \\
\hline \multirow{12}{*}{ West Eurasia } & Europe (New) & 5 & 19.0 & 8.77 \\
\hline & West Erope & 19 & 12.4 & 9.58 \\
\hline & East Europe & 35 & 6.5 & 3.49 \\
\hline & Indo-Iranian & 12 & 10.0 & 7.25 \\
\hline & India (New) & 3 & 27.8 & 3.99 \\
\hline & Indik & 5 & 7.0 & 9.00 \\
\hline & Caucasian & 45 & 27.8 & 6.09 \\
\hline & Finic-Permian & 14 & 9.6 & 7.58 \\
\hline & Ugrian & 2 & 1.5 & 2.12 \\
\hline & Samoyedic & 8 & 3.5 & 1.91 \\
\hline & Afro-Asiatic (new) & 3 & 6.8 & 2.39 \\
\hline & Afro-Asiatic & 6 & 8.6 & 3.24 \\
\hline \multirow{3}{*}{$\begin{array}{c}\text { Sub-Sahara } \\
\text { Africa }\end{array}$} & East Africa & 5 & 26.7 & 4.59 \\
\hline & South Africa & 2 & 38.4 & 20.58 \\
\hline & Khoisan & 2 & 68.7 & 24.96 \\
\hline \multirow{7}{*}{ Sino-America } & Sino-Tibetan & 4 & 10.3 & 8.25 \\
\hline & Japan & 5 & 3.5 & 1.15 \\
\hline & Taiwan aborigene & 5 & 8.7 & 9.17 \\
\hline & Altaik (Turkik) & 45 & 6.0 & 4.30 \\
\hline & Eskimo-Aleut & 11 & 20.7 & 9.80 \\
\hline & $\begin{array}{l}\text { North Indian } \\
\text { America }\end{array}$ & 13 & $11 \backslash .9$ & 7.09 \\
\hline & $\begin{array}{l}\text { South Indian } \\
\text { America }\end{array}$ & 4 & 7.6 & 2.62 \\
\hline
\end{tabular}


TABLE II (CONTINUED)

\begin{tabular}{|c|c|c|c|c|}
\hline \multirow{2}{*}{ Major region } & \multirow{2}{*}{ Group } & \multicolumn{3}{|c|}{ LM2 } \\
\cline { 2 - 5 } & & $\boldsymbol{n}$ & Mean \% & SD \\
\hline \multirow{3}{*}{ Sunda-Pacific } & South-east Asia & 1 & 10.4 & \\
\cline { 2 - 5 } & Polinesia & 6 & 18.3 & 15.66 \\
\cline { 2 - 5 } & Micronesia & 1 & 16.7 & \\
\hline \multirow{3}{*}{ Sahul-Pacific } & Australia & 4 & 9.1 & 9.09 \\
\cline { 2 - 5 } & New Guinea & 4 & 3.6 & 3.50 \\
\cline { 2 - 5 } & Melanesia & 11 & 39.4 & 15.12 \\
\hline
\end{tabular}

Note: $\mathrm{n}=$ number of sample; $\mathrm{SD}=$ standard deviation; $\mathrm{LM}=$ lower molar

\section{CONCLUSION}

Based on the results obtained from this study, it indicates that the Y-pattern is frequently found on the first molars of the Javanese. We compared the Y-pattern on the lower second molar to the frequencies in other populations studied by Scott \& Turner, and we have concluded that Javanese Deuteromalayid have a frequency of this pattern that is similar to Taiwan Aborigenese and South-American Indians. According to Scott and Turner [4], these groups of people belong to the Sino-America major region.

This is an important finding, because when we identify unknown skulls based on the teeth, we should use other dental traits to differentiate the Javanese from those of Surabayan Chinese origin. We need to look for a dental trait that is found more frequently, or that is greater in the expression, in order to assist in identifying unknown skulls that sometimes are found in the second biggest city in Indonesia.

\section{References}

[1] E. Mayr, Change of Genetic Evolution and Environment. URL: http://www.sevin.ru/fundecology/speciation/mayr(20).pdf(1954) [accessed 20 july 2017].

[2] M. Donald, Origins of the Modern Mind: Three Stages in the Evolution of Culture and Cognition. Harvard: Harvard University Press, 1991

[3] K.N. Laland, J. Odling-Smee, S. Myles, "How culture shaped the human genome: Bringing genetics and the human sciences together," Nature Reviews. Genetics, Vol.11(2) p.137, 2010.

[4] G.R.Scott, \& C.G. Turner, The Anthropology of Modern Human Teeth: Dental Morphology and Its Variation in Recent Human Populations. Cambridge: Cambridge University Press, 2000.

[5] M.D. Artaria, Antropologi Dental. Yogyakarta: Graha Ilmu, 2009.

[6] M.D. Artaria, The Prevalence of Anterior Fovea in Deuteromalayid Javanese. Australasian Society of Human Biology. Adelaide, Australia. December 2014.

[7] M.D. Artaria, Dental Traits of Sample from Manggarai (Flores): A Preliminary Study. International Conference on Flores Hominid, Yogyakarta, 2007.

[8] F. Magnis-Suseno, Etika Jawa. Jakarta: Gramedia, 1984.

[9] J. Glinka, Sekitar Terjadinya Manusia: Antropogenese. Ende: Nusa Indah, 1987.

[10] A. A. Dahlberg, "The dentition of the American Indian," in Papers on the Physical Anthropology of the American Indian. New York: The Viking Fund, 1951, pp. 138-176.

[11] G.R.Scott, \& C.G. Turner II, "Dentition," Handbook of North American Indians 3, 2006, pp. 645-60.

[12] K.D. Jørgensen, “The Dryopithecus pattern in recent Danes and Dutchmen,” J. of Dental Res., 34(2), pp. 195-208. 1955.

[13] J.D. Irish, "Characteristic high-and low-frequency dental traits in Sub-Saharan African populations," Am. J. of Phys. Anth., Vol. 102(4), pp. 455-67, 1997.

[14] N.M. King, S. Tongkoom, \& H.M. Wong, "Morphological and numerical characteristics of the Southern Chinese dentitions," Part II:
Traits in the Permanent Dentition, The Open Anthropology Journal, Vol. 3(2), pp. 71-84, 2010.

[15] A. Hasund, G. Bang, "Morphologic characteristics of the Alaskan Eskimo dentition: IV. Cusp number and groove patterns of mandibular molars," Am. J. of Phys. Anth. , Vol. 67(1), pp. 65-69, 1985.

T. Matsuda, Studies on the Dryopithecus pattern of the Japanese residing in Hokuriku District, Okajimas Fol. Anat. Japon., Vol. 37(4-5), pp. 317 30, 1961. 